\title{
BioéthiqueOnline
}

\section{Research Ethics and Commercial Drug Development: When Integrity Threatens Profitability}

\section{Jean-Christophe Bélisle Pipon}

Volume 5, 2016

URI : https://id.erudit.org/iderudit/1044268ar

DOI : https://doi.org/10.7202/1044268ar

Aller au sommaire du numéro

Éditeur(s)

BioéthiqueOnline

ISSN

1923-2799 (numérique)

Découvrir la revue

Citer cet article

Bélisle Pipon, J.-C. (2016). Research Ethics and Commercial Drug Development: When Integrity Threatens Profitability. BioéthiqueOnline, 5.

https://doi.org/10.7202/1044268ar
Résumé de l'article

Ce cas, basé sur des expériences personnelles ainsi que sur celles trouvées dans la littérature, met en évidence la tension délicate à laquelle sont confrontées les entreprises vouées au développement des médicaments soit d'équilibrer l'intégrité de la recherche et leur rentabilité.
Droits d'auteur @ J-C Bélisle Pipon, 2016

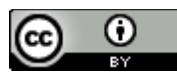

Ce document est protégé par la loi sur le droit d'auteur. L'utilisation des services d'Érudit (y compris la reproduction) est assujettie à sa politique d'utilisation que vous pouvez consulter en ligne.

https://apropos.erudit.org/fr/usagers/politique-dutilisation/ 


\title{
Research Ethics and Commercial Drug Development: When Integrity Threatens Profitability
}

\author{
ÉTUDE DE CAS / CASE STUDY \\ Jean-Christophe Bélisle Pipon ${ }^{1,2}$
}

Reçu/Received: 7 Jan $2016 \quad$ Publié/Published: 12 May 2016

Éditeurs/Editors: Marleen Eijkholt \& Hadi Karsoho

2016 J-C Bélisle Pipon, Creative Commons Attribution 4.0 International License

\section{Résumé}

Ce cas, basé sur des expériences personnelles ainsi que sur celles trouvées dans la littérature, met en évidence la tension délicate à laquelle sont confrontées les entreprises vouées au développement des médicaments soit d'équilibrer l'intégrité de la recherche et leur rentabilité.

\section{Mots clés}

capital de risque, développement des médicaments, éthique de la recherche, éthique des affaires, essais cliniques, prise de décision de l'entreprise, rentabilité

\section{Summary}

This case, based on personal experiences and on those found in the literature, highlights the delicate tension faced by drug development companies having to balance research integrity and their profitability.

\section{Keywords}

business ethics, clinical trials, corporate decision-making, drug development, profitability, research ethics, venture capital

Affiliations de l'auteur / Author Affiliations

${ }^{1}$ Bioethics Program, Department of Social and Preventive Medicine, School of Public Health, Université de Montréal, Montréal, Québec, Canada

${ }^{2}$ Institut de recherche en santé publique de l'Université de Montréal, Québec, Canada

\section{Correspondance / Correspondence}

Jean-Christophe Bélisle Pipon, jean-christophe.belisle.pipon@umontreal.ca

\section{Remerciements}

L'auteur tient à remercier Charles Dupras, Maude Laliberté, Renaud Boulanger et Bryn Williams-Jones pour leurs commentaires judicieux. L'auteur aimerait également remercier Marleen Eijkholt et Hadi Karsoho pour leurs commentaires utiles. L'auteur est soutenu par une bourse doctorats du Fonds de recherche du Québec - Santé (FRQS) \& Unité SOUTIEN-SRAP du Québec.

\section{Conflit d'intérêts}

Aucun à déclarer concernant le contenu de ce manuscrit. Cependant, l'auteur est co-fondateur de la revue.

\section{Acknowledgements}

The author would like to thank Charles Dupras, Maude Laliberté, Renaud Boulanger and Bryn Williams-Jones for their insightful comments on previous drafts of this paper. The author would also like to thank Marleen Eijkholt and Hadi Karsoho for their helpful feedback. The author is supported by a PhD scholarship from the Fonds de recherche du Québec - Santé (FRQS) \& Unité SOUTIENSRAP du Québec.

\section{Conflicts of Interest}

None to declare regarding the content of this paper, however the author is co-founder of this journal.

\section{Introduction}

The development of a new drug is a complex and daunting endeavour, and biotechnology companies may find themselves torn between their financial interests and the interests of research participants. In this paper, I present a case study that describes, from the perspective of a decision-maker within a pharmaceutical company, the elements that can lead to having to choose, under commercial and financial pressures, between the integrity of the conduct of drug development and the profitability of a company. Such a dilemma may appear for some as simplistic - by watering down the complexity of ethical decision-making processes - but is rather good at showcasing how a company must deal with two core values (integrity versus profitability) to remain in business [1]. Corporate image and commercial efficiency may not be at the core of the moral dilemma from a bioethical standpoint, and research ethics might demand that the obvious primary responsibility, no matter the context, is above 
everything else the protection of participants [2]. However, from a pragmatic point of view, sophisticated ethical issues may not be the primary focus of a set of actors with very different concerns who are incentivized to voluntarily choose to disregard ethical imperative in favour of shortterm gains [3,4]. Based on what biotechnology firms are continuously facing to stay in business [5], this case serves to highlight the importance of the pressure experienced by actors in competitive commercial contexts [6,7] and enriches the discussions in bioethics about the ethical conduct of companies [8-10].

\section{The Case}

The discovery of a promising new medication brings great joy and hope to many researchers, to patients seeking effective treatment and, more broadly, to the business community and society. Most experimental medications, however, never reach the market, and the commercialization of even the most promising few is a long, arduous, and costly endeavour.

A small Canadian private biotechnology company BioMelior ${ }^{1}$ has succeeded in developing a promising molecule $\left(B i o M-890^{2}\right)$ demonstrating a reversing effect on Alzheimer's disease. The drug would represent the first drug to prevent the symptoms from getting worse and to show a moderate improvement over time. As the demand for Alzheimer's treatments is high in wealthier countries, the population is expected to be large enough for the drug to be profitable and the therapeutic offer (i.e., competition) is still limited. BioM-890 has recently been patented and the company was able to obtain funding from venture capital $(\mathrm{VC})^{3}$ to further push the development of the product. However, the company's resources are limited, the financial risk remains very high and commercialization is still far off and uncertain. As with any drug development, BioMelior needs to take the following steps: conduct preclinical trials (laboratory and animal testing) and the three clinical trial phases on humans in order to collect the necessary data to request approval by Health Canada [11].

Due to the limitations of BioMelior's human, material and infrastructural resources, management decided to deal with a contract research organization (CRO). Considering that the clinical trials are the most expensive aspect of drug development [12], outsourcing is a common practice in the industry as a means of significantly reducing costs $[13,14]$. The Indian-owned CRO AlphaLab ${ }^{4}$ was identified for preclinical trials since it excels in conducting such research, and a service offer was commissioned. In the details of the offer, AlphaLab proposed to add provisions for the conduct of phase I to III clinical trials if the molecule is compliant (safe and efficient) enough to continue development (see Figure 1, option 1). AlphaLab offers a considerable price reduction compared to the market price of conducting clinical trials with human participants and faster deliverables for a complete package, including preclinical and clinical phases.

This offer represents a very advantageous solution considering BioMelior's limited resources, as it would reduce the financial risk for both the company and its VC partners. Although the decision rests with upper management of the company, pressure by the partners is strong to sign an exclusive contract with AlphaLab. However, while effective and recognized in preclinical research, AlphaLab does not have a very good reputation for tests with human participants. In recent years, the CRO faced allegations from some media for unethical participant recruitment in Asia, as the CRO conducts these trials largely in India and China. Even if presumed compliant with international standards for good clinical trials, AlphaLab works with local subcontractors which might raise a number of ethical concerns: the CRO will only remotely oversee the conduct of research and BioMelior will have no control over the selection of local subcontractors whose conduct and reputation may not be

\footnotetext{
${ }^{1}$ BioMelior is a fictional company.

${ }^{2}$ BioM-890 is a fictional molecule.

${ }^{3}$ Venture capital is a type of investment in the early-stage of a company or a product when profitability is uncertain. It is also referred to as "risk capital".

${ }^{4}$ AlphaLab is a fictional company.
} 
advantageous considering that they may have a "flexible" definition of what constitutes an ethical trial. That being said, in the last few months AlphaLab has changed ownership and the new administration revamped their standard operating procedures. In light of this transition, some experts see the changes as promising signs, but this does not constitute a strong guarantee.

To get a better idea of the options and to assess the potential savings achieved by doing business with AlphaLab, BioMelior's leaders seek other CROs working particularly in phases I to III (See Figure 1, option 2). Of the proposals, only one stands out. Nearly three times more expensive than AlphaLab's tender, the Canadian-based CRO BetaLab ${ }^{5}$ performs all its trials in Canada, even if this is not a requirement under Canadian regulation, following the Tri-Council Policy Statement: Ethical Conduct for Research Involving Humans (TCPS2) ${ }^{6}$ as well as ICH's Good Clinical Practice ${ }^{7}$. The price comes with, among other things, the insurance of high medical standards, constant monitoring of the participants, and appropriate informed consent. BetaLab has a very good reputation with a long history of collaboration with Canadian health care institutions.

Figure 1 - Options for the Conduct of Drug Development Phases

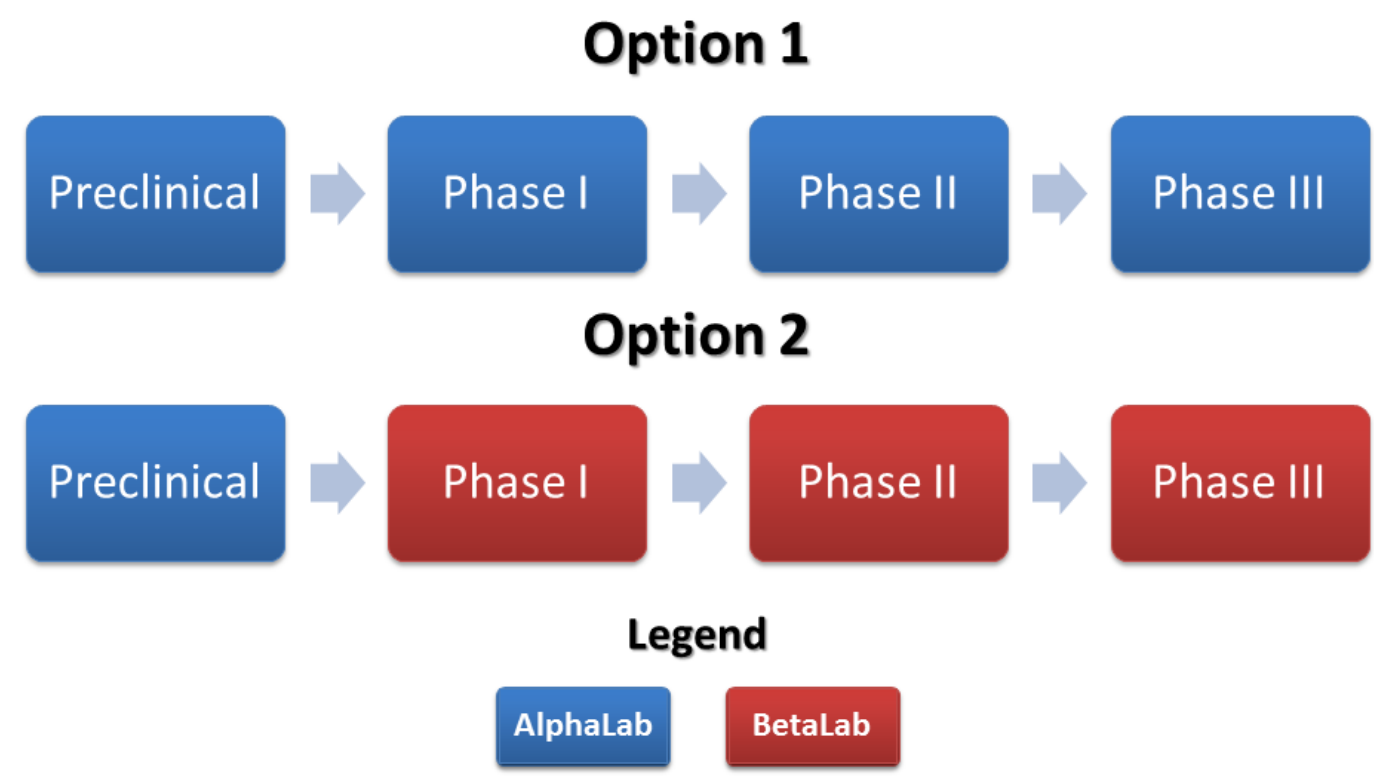

There are two options for the conduct of drug development phases. Option 1 provides an exclusive contract to the firm AlphaLab and thus can generate big savings. Option 2 maintains the preclinical phase with AlphaLab, but all further phases involving human subjects will be conducted with BetaLab.

\section{The Decision}

Given the importance for BioM-890's development potential and, more broadly, the BioMelior's financial future and the welfare of participants, concerns about which CRO to choose were raised at a meeting of the company Board of Directors (the Board). From the beginning of the session, it becomes clear that the CRO choice is a source of great tension among the administrators. Some hold the opinion that the decision should focus on which CRO is the most capable of running compliant clinical trials, while others are more concerned about costs and profitability.

\footnotetext{
${ }^{5}$ BetaLab is a fictional company.

${ }^{6}$ The TCPS, revised in 2014, is the leading document in research ethics in Canada. It is only required for studies conducted with funds from Canadian granting councils, which would not normally be the case for a biotechnology company like BioMelior. For more information, see [15].

${ }^{7}$ The International Conference on Harmonisation $(\mathrm{ICH})$ sets the international standards applying to clinical trials on human subjects, called Good Clinical Practices (GCP). For more information, see [16].
} 
During the discussion, two board members argue for diametrically opposed considerations which have great influence on all other members. On the one hand, Ms. Smith, a former member of a private Research Ethics Board (REB), argues about the importance of reputation, responsibility for the respect of participants, the financial risks, and the associated delays of a research protocol rejection by the private REB contracted by BioMelior. According to Ms. Smith, BetaLab is offering more control over the trials and respecting the highest standards in the conduct of tests. Thus, choosing Betalab would minimize the risks arising from sloppy trials, thereby better serving BioMelior's commercial interests in addition to complying with the strict requirements of Canadian regulations and REB standards. She claims that Option 2 is the only viable solution. On the other hand, Mr. Taylor, a member representing VC partners, threatens to withdraw VC investment if BioMelior deals with BetaLab, the most expensive CRO, as they charge three-time more than AlphaLab for phase I to III. $\mathrm{He}$ indicates that it is better to opt for the solution that will ensure the development and profitability of BioM-890, so Option 1 must be chosen. In his experience, only $11 \%$ of molecules reach the market [17], so it would not be to the advantage of the company nor patients if the development of this promising drug was stopped for lack of funding. Furthermore, he indicates that the change of ownership is a good sign and that the CRO AlphaLab, being bound by contract, is solely responsible for its actions and contingent misconduct.

As a Board member, you must decide between the proposal of AlphaLab or BetaLab for conducting phases I to III. The future of the product (and, to some extent, of the company) may depend on this decision (see Figure 2). On the one hand, the product, expected to be a breakthrough in a promising market, could relieve patients and provide them with a solution for their nearly untreated condition. On the other hand, the company's financial resources are limited and the VC partners' threat of withdrawing their funding if the product development costs exceed what was initially budgeted. This threat is real and could mean the end of BioM-890 development. Still, flaws in research integrity could also be very harmful for the development and approval processes, and could even risk leading to a scandal when the product is marketed. 


\section{Figure 2 - Decision-making Process within BioMelior's Organizational Chart}

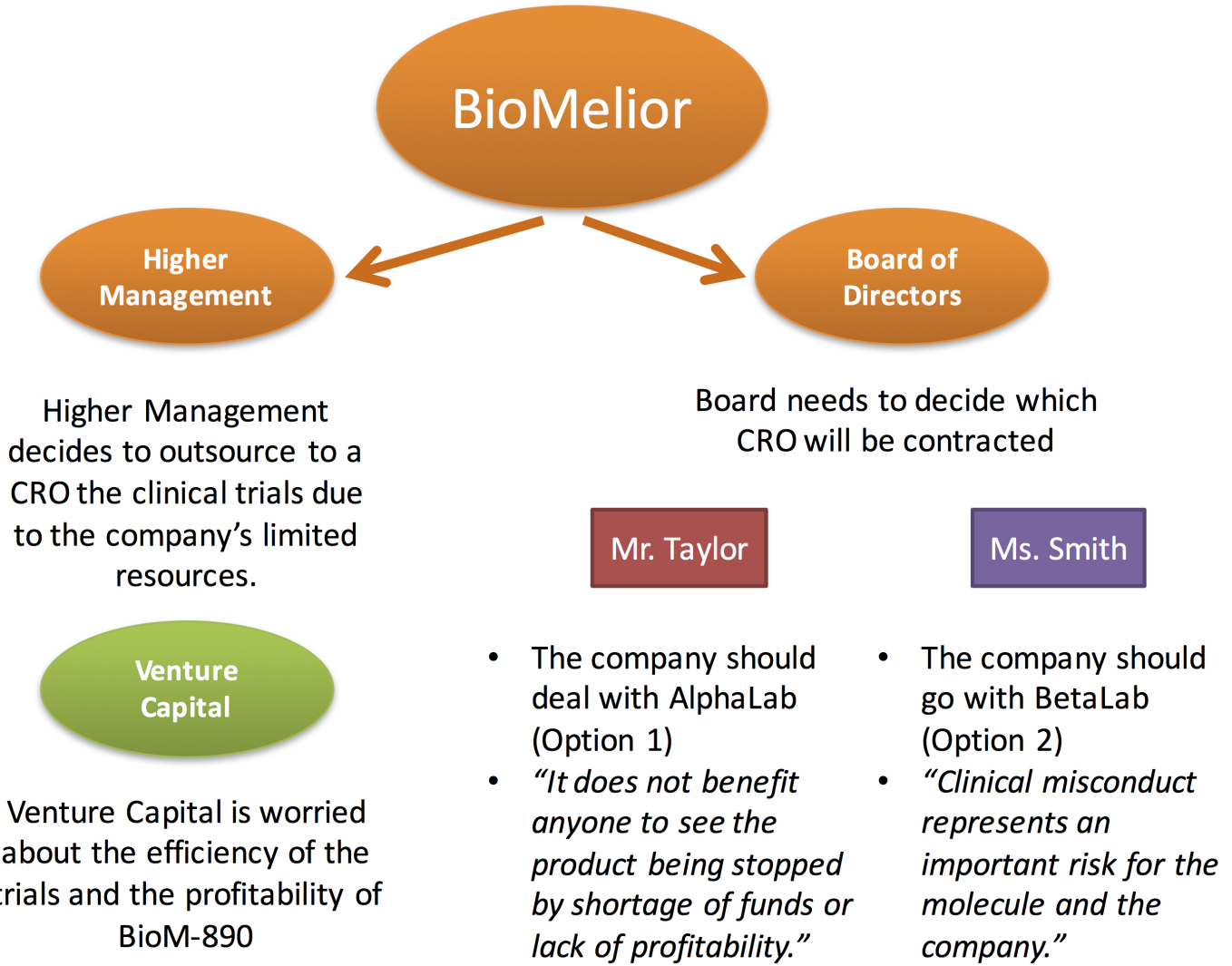

As a member of the Board, you have to decide between the two options as per Mr. Taylor's and Ms. Smith's suggestions.

\section{Reasoning: Between Integrity and Innovation}

\section{Actors and influences}

- The situation has several actors who each have a different influence on the situation and have their own interests.

- How many different actors do you identify? How many different "interests" are there?

- What are the competing interests of one or more actors? What are the converging interests of one or more actors?

- Are there any conflicts of interests? And if so, for whom?

- Who is the dominant actor? Are its interests overruling others? Does this affect (or should it affect) the decisions of the other actors?

\section{Integrity and Research Ethics}

- Ms. Smith argues that reputation and responsibility are important dimensions of drug development.

$\circ$ Does the fact that clinical trial's local decision-making is made by a third party rather than directly by BioMelior's headquarters (due to the outsourcing of the clinical trial) have a negative impact on the image and accountability of the company? Why?

- Does outsourcing to a CRO reduce BioMelior's responsibility because another entity manages the clinical trials? 
- Who is ultimately responsible for ensuring that the ethical standards are followed? Or is it a shared responsibility, and if so, between whom?

- The development of BioM-890 is conducted completely in the private sector, without any collaboration with university researchers or the major public granting councils. Therefore, the Tri-Council Policy Statement (TCPS2), the Canadian flagship research ethics document, does not apply.

- Does the fact that the company is dealing with a private REB have an influence on the ethical review of its clinical trials? What kind of influences might be at stake?

- Are the integrity of the drug development process and the ethical conduct of clinical trials with humans compromised by the fact that respect for the TCPS2 is not required?

- Is this situation desirable? What would be the best solution to ensure an efficient ethical evaluation of such clinical trials?

\section{Innovation and Business Ethics}

- The argument of Mr. Taylor suggests that the financial risks (e.g., expenditures incurred, delay in development and in the marketing of the product) are too important, and thus there is an imperative to sign with AlphaLab to protect the product's profitability.

- Who would assume most of the risks? The research participants or the venture capital investors?

- Corollary: Are the risks taken by VC investors being inappropriately transferred to research participants?

- Is the power of the funders (exemplified by the statements and actions of Mr. Taylor) too great? Is it limiting the decisional independence of the Board?

- How should one weigh the importance of developing a promising drug compared to the ethical pitfalls associated with the approval and commercialization of the product?

- Is it possible, and if so how, to prioritize between integrity and profitability?

- Is it justifiable to conduct research without decent integrity assurance if the expected outcomes for the patients are greater than the risks for the research participants?

- Does this influence innovation possibilities and commercial development? Is it desirable?

\section{The Verdict}

- Under the conditions presented in this case, for which CRO would you vote as a member of the Board of Directors? What are the values and interests guiding your decision?

\section{References}

1. MacDonald C. Business ethics 101 for the biotech industry. BioDrugs. 2004;18(2):71-7.

2. Fortin J-S, Bélisle Pipon J-C, Ganache I. Visées éthiques, développement et usage du médicament. In: Beaulieu P, Pichette V, Desroches J, du Souich P, editors. Précis de Pharmacologie. 2nd ed. Montréal, Québec: Presses de l'Université de Montréal; 2015. p. 1011-21.

3. Bélisle Pipon J-C, Williams-Jones B. Drug Familiarization and Therapeutic Misconception via Direct-To-Consumer Information. Journal of Bioethical Inquiry. 2015;12(2):259-67.

4. Bélisle Pipon J-C, Williams-Jones B. Regulating Direct-to-Consumer Drug Information: A Case Study of Eli Lilly's Canadian 40over40 Erectile Dysfunction Campaign. Healthcare Policy Politiques de Santé. 2015;10(4):16-23.

5. Thakur P. Offshoring and outsourcing of core corporate activities: The global relocation of pharmaceutical industry clinical trials. [PhD]: Rutgers, The State University of New Jersey Newark; 2010. 
6. Bélisle Pipon J-C. De la binarité au modèle AI3R : la bioéthique écosystémique comme modèle d'analyse normative de l'industrie biopharmaceutique. [Masters]. Montréal, Québec: Université de Montréal; 2013.

7. Bailey R. Deciding about your health care: the ethicist as policy-maker. Health Care Analysis. 2001 Oct 1;9(3):265-81.

8. Lipworth W, Little M. Deriving and critiquing an empirically based framework for pharmaceutical ethics. AJOB Empirical Bioethics. 2014 Jan;5(1):23-32.

9. Lipworth W, Montgomery K, Little M. How pharmaceutical industry employees manage competing commitments in the face of public criticism. Journal of Bioethical Inquiry. 2013;10(3):355-67.

10. Klopfenstein M, Campen LEV, Garnett T. Expanded access programs: ethical and practical considerations for biopharmaceutical sponsors. Therapeutic Innovation and Regulatory Science. 2015;49(3):352-8.

11. Health Canada. Drug Licensing Process. 2007.

12. Patented Medicine Prices Review Board. Annual Report 2014. Ottawa: Government of Canada; 2015.

13. Schubert C. Pharmaceutical sector: Delicate transition. Nature. 2012;486(7402):281-3.

14. Nicholas J. Outsourcing Clinical Trials. Journal of the National Cancer Institute. 2012;104(14):1043-5.

15. Canadian Institutes of Health Research, Natural Sciences and Engineering Research Council of Canada, Social Sciences and Humanities Research Council of Canada. Tri-Council Policy Statement: Ethical Conduct for Research Involving Humans. 2014

16. Health Canada. Guidance for Industry: Good Clinical Practice: Consolidated Guideline - ICH Topic E6. Government of Canada; 1997.

17. Alex AA, Storer RI. Chapter 1: Drugs and their structural motifs. In: Metabolism, Pharmacokinetics and Toxicity of Functional Groups: Impact of Chemical Building Blocks on ADMET. 2010.

\section{Suggested Readings}

1. Adobor $\mathrm{H}$. Ethical issues in outsourcing: the case of contract medical research and the global pharmaceutical industry. Journal of Business Ethics, 2012;105(2):239-255.

2. Craven R. Testing times for clinical research. The Lancet Neurology, 2010;9(2):144-145.

3. Emanuel EJ, et al. What makes clinical research in developing countries ethical? The benchmarks of ethical research. Journal of Infectious Diseases, 2004;189(5):930-937.

4. Matlin SA, Samuels GMR. The global health research and innovation system (GHRIS). The Lancet, 2009;374(9702):1662-1663.

5. Stewart JJ, Allison PN, Johnson RS. Putting a price on biotechnology. Nature Biotechnology, 2001;19(9):813-818.

6. Taylor N. Biopharmaceutical outsourcing deals evolving as market matures. Nature Biopharma Dealmakers, B2-B5, 2013. 